Historia Slavorum Occidentis

2020, nr $3(26)$

ISSN 2084-1213

DOI: $10.15804 /$ hso200306

\author{
MaŁgorzata Nossowska (Lublin)
}

ORCID: 0000-0002-4754-2400

\title{
„Un Bourgeois” w Kraju Rad. Georges’a Le Fèvre’a wrażenia z podróży do Związku Radzieckiego
}

Słowa kluczowe: Obraz ZSRR we Francji, „Le Journal”, prasa francuska, dwudziestolecie międzywojenne, relacje rosyjsko-francuskie, Georges Le Fèvre

Keywords: The image of the USSR in France, "Le Journal”, French press, the Interwar period, French-Russian relations, Georges Le Fèvre

Abstract: The text is dedicated to G. Le Fèvre, a French journalists and his account of his travel across the USSR in 1929. "Le Journal”, a popular Paris newspaper, published it under the title "Un Bourgeois au pays des sovièts".

Początek 1930 r. czytelnicy jednego z najbardziej popularnych dzienników francuskich, „Le Journal”, rozpoczęli wraz z pisarzem i dziennikarzem Georges'em Le Fèvre'em ${ }^{1}$ wędrówką po egzotycznym nieco dla nich, ale zawsze fascynującym i budzącym zainteresowanie terytorium Rosji. Pośród swoich licznych książek-reportaży

1 Georges Le Fèvre (1892-1968), francuski dziennikarz, pasjonat rajdów samochodowych i podróży rowerowych, od czasu Wielkiej Wojny wspólpracownik kilkunastu gazet, autor książek, które można określić jako reporterskie, m.in.: Bagnards et Chercheurs d'Or (1925), Démolisseurs et Bâtisseurs (1927), L'Epopée du Caoutchouc (1927), Je suis un Gueux. A Londres. A Berlin. A Paris (1929), Au secours de la Couture (1929), Homme-Travail (1930), Les Marchands d'Espace (1939), Sa majesté le pétrole (1950), współpracownik kilkunastu gazet. O pasji rajdowej Le Fèvre'a zob. Georges Le Fèvre ce Sadiracais oublié, http://www.edmwebtv.com/ archives/7526 [dostęp 25 X 2019]. 
w 1929 r. Georges Le Fèvre wydał opowieść o swojej kilkutygodniowej podróży po Związku Radzieckim Un Bourgeois au pays des sovièts. Ta licząca sobie 256 stron książeczka (wydanie broszurowe) w obszernych fragmentach ukazała się na łamach „Le Journal”, przybliżając jego czytelnikom obserwacje i refleksje Le Fèvre’a, tworząc ciekawy, intrygujący, chwilami zabawny, chwilami tragiczny, ale zawsze barwny i soczysty obraz Rosji radzieckiej dwanaście lat po rewolucji - cel, który postawił sobie autor, wyruszając w swoją podróż. Była to jedna z tych podróży, które organizowane pod oficjalnym nadzorem państwa można zaliczyć do jednego z ważniejszych narzędzi propagandowych służących budowaniu pozytywnego wizerunku ZSRR w oczach społeczeństw zachodniej Europy. Proces ten, rozpoczęty tuż po wojnie domowej, kiedy nową Rosję odwiedziło z ciekawości lub ideologicznego czy politycznego zaangażowania wielu zachodnich intelektualistów, pisarzy, artystów i uczonych, nabrał znaczenia na przełomie lat dwudziestych i trzydziestych, a z wielką intensywnością był realizowany po dojściu Hitlera do władzy². Neutralizowano lęki i strach przed rozlaniem się rewolucji po świecie Zachodu silne na początku lat dwudziestych, starano się odebrać wiarygodność relacjom o terrorze i łagrach, a jednocześnie umocnić w lewicujących kręgach intelektualistów przekonanie o tym, że Kraj Rad wciela w życie najbardziej postępowy projekt społeczny, przygotowywano grunt do współpracy, wspierano coraz silniejsze od początku lat trzydziestych ruchy lewicowe w różnych krajach europejskich ${ }^{3}$. Jednym ze skuteczniejszych sposobów realizowania tychże zadań propagandowych było wprzęgnięcie $w$ ten proces ludzi pióra, pisarzy i dziennikarzy, wykorzystanie masowej prasy, organizowanie (pod ścisłym nadzorem) podróży po ZSRR, opisywanych potem w prasowych i książkowych relacjach, staranna selekcja tych, którzy otrzymywali akredytację (casus „The Times") czy wizy wjazdowe ${ }^{4}$.

We Francji nie trzeba było w szczególny sposób tego zainteresowania stymulować. Rosja, niezależnie od jej kolejnych politycznych odsłon i oficjalnej nomenkla-

2 Rozważaniom tym poświęcił R. Pipes cały IV rozdział swojej książki (Komunizm na eksport). R. Pipes, Rosja bolszewików, Warszawa 2005, m.in. s. 267-270, 273-274, 308-315. Ciekawe ujęcie również: D. Tołczyk, Gułag w oczach Zachodu, Warszawa 2009, s. 65-82, 97-105, 121-138.

3 Szczególnie ekonomicznej po Wielkim Głodzie (cezura ważna dla ZSRR) i rozlaniu się po świecie Wielkiego Kryzysu, który uczynił rządy państw Zachodu zdecydowanie bardziej skłonnymi do współpracy z Krajem Rad. D. Tołczyk, Gułag w oczach, s. 82-83, 102-104; T. Snyder, Skrwawione ziemie. Europa między Hitlerem a Stalinem, Warszawa 2018, s. 100-107, 140; R. Pipes, Rosja bolszewików, s. 266-274.

4 D. Tołczyk, Gułag w oczach, s. 78-81, 129-133. 
tury, uwagę przyciągała zawsze. Odległa, ale budząca zainteresowanie, egzotyczna, ale jednocześnie stosunkowo bezpieczna, łącząca polityczne i ekonomiczne interesy $\mathrm{z}$ chęcią dotknięcia nieznanego, które uwodziło swoim urokiem. Problem francusko-rosyjskich relacji i fascynacji, to temat ogromny, na różnych płaszczyznach szeroko analizowany ${ }^{5}$, trudno zmierzyć się z nim na kilku stronach tego tekstu, ale koniecznie należy podkreślić trzy rzeczy: po pierwsze, silne, choć może nieco jednostronne $e^{6}$, związki kulturalne, po drugie, polityczne znaczenie, jakiego nabrała dla Francji Rosja w ciągu XIX i XX w., po trzecie, szczególne zainteresowanie Rosją radziecką w dwudziestoleciu międzywojennym w kontekście spraw ideologicznych, ekonomicznych oraz francuskiej polityki zagranicznej ${ }^{7}$. I to niezależnie od tego, czy patrzono na nią jako kraj nadziei, czy też wynaturzonego potwora zagrażającego naturalnemu porządkowi świata ${ }^{8}$. Wielu francuskich intelektualistów, pisarzy, dziennikarzy i w la-

5 Np.: A. Lortholary, Le mirage russe en France au XVIIIe siècle, Paryż 1951; F. Furet, Przeszłość pewnego złudzenia. Esej o idei komunistycznej w XX wieku, Warszawa 1996; B. Cambournac, Trois siècles de relations franco-russes, constats et perspectives, Revue Russe, 6 (1994). La Russie et la France. Trois siècles de relations. Actes du colloque organisé à SaintLô et à l'abbaye d'Hambye par le Conseil général de la Manche, les 17 et 18 septembre 1993, s. 7-10, http://www.persee.fr/doc/russe_1161-0557_1994_num_6_1_1814 [dostęp $25 \mathrm{X}$ 2019]. Poświęcono też temu problemowi znaczną część numeru 2-3/2002 Cahiers du monde russe. Contacts intellectuels, réseaux, relations internationales. Russie, France, Europe, XIIIe-XXe siècle. Dostęp do wszystkich tekstów: https://www.cairn.info/revue-cahiers-du-monde-russe-2002-2.htm [dostęp 25 X 2019]. Por. też przyp. 8.

6 Pokazał to znakomicie Orlando Figes w Tańcu Nataszy opisując m.in. dominującą pozycję j. francuskiego wśród rosyjskich elit. O. Figes, Taniec Nataszy. Z dziejów kultury rosyjskiej, Warszawa 2010, s. 36-39. Drugą stronę wzajemych relacji: zob. m.in.: M. Niqueux, La France et les Français vus par les voyageurs russes (XVIIIe-XIXe siècles), Revue Russe 6 (1994) s. 59-69; J. Bonamour, La littérature russe en France à la fin du XIXe siècle: la critique française devant $\gg l$ 'âme slave «, tamże, s. 71-79.

7 Szczególnie w kontekście zmian w polityce zagranicznej Francji wobec Rosji w okresie międzywojennym zakończonych podpisaniem układu z 1932 r., zmian, których istotną część stanowił element ekonomiczny związany z Wielkim Kryzysem. Zob.: M. Wołos, Francja - ZSRR. Stosunki polityczne w l. 1924-1932, Toruń 2004; A.M. Brzeziński, Zagadnienia bezpieczeństwa zbiorowego w Europie w polityce zagranicznej Francji (1919-1939), Łódź 1992; G.-H. Soutou, Le deuil de la puissance (1914-1958), [w:] J.-C. Allain, P. Guillen, G.-H. Soutou, L. Theis, M. Vaïsse, Histoire de la diplomatie française. T.II De 1815 à nos jours, Paris 2007, s. 318-329; R. Pipes, Rosja bolszewików, 284-293. Ciekawy, syntetyczny zarys tej problematyki zob.: A.M. Jackowska, Sowiety na tawie oskarżonych. Polskie uczestnictwo w propagandowej zimnej wojnie we Francji w latach 1947-1952, Warszawa 2018, s. 16-33.

8 Pierwszy punkt widzenia widoczny jest w sile lewicowych fascynacji Rosją, czy ideami, które z nią utożsamiano, na drugi w pewnym stopniu wplywała silna kolonia białych Rosjan, która 
tach dwudziestych, i później odwiedziło ZSRR, wielu, z różnych powodów, pisało, czy mówiło o nim z zachwytem lub „z pozytywną konkluzją” mimo pewnych uwag krytycznych. André Malraux, Louis Aragon, Romain Rolland, André Gide, to tylko ci najwybitniejsi, choć akurat André Gide wyleczył się ze swojej fascynacji po zetknięciu się z radzieckimi realiami w $1936 \mathrm{r}$. $^{9}$

Jak pisał Richard Pipes, tylko w latach 1918-1924 wydano we Francji 34 książki będące relacjami z Rosji ${ }^{10}$. W tym kontekście drukowany w poczytnym dzienniku popularnym na pierwszej, strategicznej, stronie reportaż Le Fèvre'a z ZSRR miał szansę przyciągnąć uwagę czytelników, a także wpłynąć na ich sposób postrzegania tego kraju. Ukazujący się od 1892 r. „Le Journal” od początku swojego istnienia należał do tzw. „wielkiej czwórki”: czterech najbardziej popularnych i poczytnych dzienników francuskich ${ }^{11}$. Gazety te balansowały często pomiędzy wiarygodną informacją a plotką i skandalem, nie zawsze sięgały do najbardziej wiarygodnych źródeł i istotnych treści, ale stanowiły jedno z najważniejszych „okien na świat” francuskiego czytelnika. Informowały, poruszały, kreowały wizerunki i mody, przyciągały uwagę do konkretnych problemów, a na przedostatnią stronę spychały inne, były często najważniejszym źródłem informacji o tym, co działo się w świecie. I choć lata

w drugiej połowie lat dwudziestych ukształtowała się w Paryżu, czy postawa konserwatywnej części francuskiej sceny politycznej. Zob. np.: S. Coeuré, la Grande Lueur à l'est. Les Fançais et l’Union soviétique 1917-1939, Paris 2017; F. Furet, dz. cyt.; T. Judt, Historia niedokończona. Francuscy intelektualiści 1944-1956, Warszawa 2012; H.R. Lottman, Lewy brzeg. Od frontu ludowego do zimnej wojny, Warszawa 1997; N. Racine-Furlaud, Le parti socialiste (S.F.I.O.) devant le bolchevisme et la Russie soviétique, 1921-1924, Revue française de science politique 2 (1971), s. 281-315, https://www.persee.fr/doc/rfsp_0035-2950_1971_num_21_2_418050 [dostęp 25 X 2019]; J.-N. Ducange, A. Tchoudinov, La révolution comme modèle et miroir (URSS, Chine, Japon), Annales historiques de la Révolution française 1 (2017), s. 3-8, https:// www.cairn.inforevue-annales-historiques-de-la-revolution-francaise-2017-1-page-3.htm [dostęp 25 X 2019], a także inne teksty z tego numeru; N. Struve, Soixante-dix ans d'émigration russe 1919-1989, Paris 1996, s. 21-23, 108-111, 113-114; A. Jevakhoff, Les Russes blancs, Paris 2011, s. 229-231; tenże, Le Roman des Russes à Paris, Paris 2014, s. 203-253.

9 Zob. H.R. Lottman, Lewy brzeg.

10 R. Pipes, Rosja bolszewików, s. 193-196.

11 Obok „Le Journal” były to: „Le Petit Parisien”, „Le Petit Journal”, „Le Matin”. W szczytowym okresie popularności ukazywały się w łącznym nakładzie 4,5-5 mln egz., a czytane były przez ok. 4 razy większą liczbę odbiorców. Ch. Delporte, C. Blandin, F. Robinet, Histoire de la presse en France. $X X^{e}-X X I^{e}$ siècles, Paris 2016, s. 13-16, 43; Histoire générale de la presse française poub. sous la dir. de C. Bellanger, J. Gochochot, P. Guiral et F. Terrou, Paris 1972, t. 3, s. 136-137, 296, 428; D. Lormier, Histoire de la presse en France, Paris 2004, s. 41. 
świetności „Le Journal” miał już za sobą, to pozostawał cały czas znaczącym tytułem, sprzedającym się na przełomie lat dwudziestych i trzydziestych w ok. sześciusettysięcznych nakładach ${ }^{12}$.

Opowieść Le Fèvre’a o Rosji, to seria obrazów, które w pojedynczych scenach starały się uchwycić istotę życia w nowej, radzieckiej rzeczywistości, istotę systemu i tworzących go ludzi, za pomocą szczegółu próbujące oddać sedno tego, czym wg autora stała się Rosja. Pilnie obserwował, pytał, niekiedy budząc pytaniami dezorientację, rozmawiał, rzadko polemizował, co najwyżej dziwił się, ale wyraz swojemu sceptycyzmowi dawał wyraźnie raczej w ironicznych komentarzach, doborze określeń, niekiedy wprost w tytułach rozdziałów/felietonów, rzadko w bezpośrednich rozmowach ${ }^{13}$. Pod wspólnym mianem Un Bourgeois au pays des sovièts pomiędzy 5 styczniem a 4 lutym ukazało się trzydzieści ${ }^{14} \mathrm{dwu}$ - lub trzykolumnowych tekstów przekazujących w felietonowo-reporterskiej formie wrażenia z pobytu w Rosji francuskiego dziennikarza. Wrażenia człowieka obdarzonego dużym zmysłem obserwacji i wrażliwością ${ }^{15}$, zauważającego pozornie nieistotne szczegóły, otwartego na nowe przeżycia, ale i krytycznego, choć nie afiszującego się nadmiernie ze swoimi poglądami w trakcie podróży po ZSRR.

Przekroczenie granicy polsko-radzieckiej w Stołopcach-Niegoriełoje Le Fèvre potraktował jako przekroczenie granicy cywilizacji, granicy dzielącej dwa światy, dwie filozofie życia, kompletnie różne porządki polityczne, ale też i mentalne ${ }^{16}$. Pierwsze kroki i pierwsze wrażenia to Moskwa. Jak pisał - miasto nieprawdziwe już, nie będące sobą, a urzeczywistnieniem i ucieleśnieniem systemu ${ }^{17}$. Przeszłość zastygła tu zamrożona, istniejąc tylko w muzeach i na kartkach pocztowych, ale za to w jakim do tego kontraście istnieje teraźniejszość! Zainstalowała się wszędzie narzucając swój język, ulica była tylko agresywnym komunikatem wykrzyczanym z plakatów na fasadach budynków i zza sklepowych witryn. Komunizm mówił do przechodnia, zaczepiał go, atakował. Podnosząc oczy, aby przeczytać nazwę ulicy,

\footnotetext{
12 Ch. Delporte, C. Blandin, F. Robinet, Histoire de la presse, s. 68, 92-94.

13 Np. „L'esclave Rouge” - czerwony niewolnik, w felietonie poświęconym robotnikom rolnym pracujących w sowchozach, czy „L'école déficit” - szkoła deficytu, o opłacalności ekonomicznej tychże.

14 Jedynym wyjątkiem był 22 I $1930 \mathrm{r}$.

15 Świadczą o tym jego teksty i sprawy, na które zawracał uwagę pracując jako dziennikarz, m.in. reportaż opowiadający o świecie bezdomnych w największych metropoliach Europy Je suis un Gueux. A Londres. A Berlin. A Paris, Paris 1929.

16 Contact, „Le Journal” (dalej: J), 5 I, s. 1.

17 Décor soviétique, J, 6 I, s. 1.
} 
dziennikarz widział uderzające go wręcz brutalnie słowa: „Kapitalizm tworząc wielkie posiadłości doprowadził do śmierci milionów chłopów, władza radziecka obroniła te miliony przed biedą i ruiną”. Albo: „wszystko dla nieprzerwanego tygodnia! wyrzućmy na zawsze niedzielę, ten dzień księży, pijaków i leniów!”. Ulica mówiła, nakazywała, myślała i decydowała za przechodnia, uczyła nowej Rosji. Sklepy nowego, państwowego rodzaju zaspokajające i ujednolicające wszystkie potrzeby, stroje przechodniów, mężczyzn i kobiet, starych i młodych, neutralne i stosowne, unifikujące, niewyróżniające się, niemówiące nic o ich pochodzeniu czy zawodzie. Doskonale przezroczysty, jeden podobny do drugiego, obywatel radziecki. Dziwne miasto, które przemawiało, zachęcało, tłumaczyło podobne w tym do państwa, które równie było wszędzie, organizowało wszystko, wyprzedzało każdy krok i decyzję. Wrażenie wszechogarniającej propagandy, idei atakujących przechodnia na każdym kroku, a związanych z komunizmem, zawłaszczających kolejne sfery życia, to najbardziej wyraziste, przytłaczające odczucie Le Fèvre’a związane ze zwiedzaniem Moskwy.

Wszechobecną szkołą nowego systemu były nie tylko ulice Moskwy. Była nią też cała, szeroko rozumiana kultura oraz „oeuvres culturelles”, sformułowanie, które u Le Fèvre’a budziło jak najgorsze i zupełnie nie-kulturalne skojarzenia ${ }^{18}$. Widział je, owe „oeuvres culturelles”, w jednej z kopalń niedaleko Rostowa ${ }^{19}$, obserwując pracowników kultury (jak nazywał artystów pracujących dla państwa) w Leningradzie ${ }^{20}$ czy repertuar teatralny ${ }^{21}$. Zadziwiło go spotkanie młodzieżowej sekcji wychowania fizycznego, w trakcie którego gorąca dyskusja nad polecanymi lekturami wprawiła młodych ludzi w trans, niemalże jak po użyciu alkoholu, a jego samego pozostawiła z poważną wątpliwością, czy aby na pewno brał udział w spotkaniu sekcji kultury fizycznej. Podobne zdumienie towarzyszyło Le Fèvre'owi, kiedy znalazł się w siedzibie związku pracowników sztuki i zobaczył artystę-malarza dowiadującego się pokornie w sekretariacie, czy były zamówienia państwowe na jego usługi. A sztuki teatralne? Dopiero one ukazywały w pełni zaangażowanie kultury w proces budowania nowego państwa. Silnie wybrzmiewające tezy polityczne, retoryczny język, bohater będący „czystym komunistą” skontrastowany ze swoim przeciwnikiem, często „złym bratem”, który nie dostrzegał głębi i wartości zmian rewolucyjnych, typem prowoka-

\footnotetext{
18 „Oeuvre” można chyba najlepiej w tym kontekście przetłumaczyć jako wytwór, produkt. Le club de la mine, J, 26 I, s. 1.

19 Tamże.

20 Les travailleurs de l'art, J, 28 I, s. 1.

21 Le drame soviétique, J, 1 II, s. 1-2.
} 
tora, tchórza i bandyty. Byli też zawsze przedstawiciele starego świata, „zagubione owieczki”, często oficer czy uczony, którzy w wyniku wydarzeń opisanych w sztuce pojmowali doniosłość rewolucyjnej zmiany i godzili się z nowym systemem. Rewolucja, żeby zostać zaakceptowana, musi być zrozumiana. Wrogość to wynik niewiedzy. Oto zadanie „oeuvres culturelles”: edukacja mas przez będących ramieniem państwa artystów. A co było najważniejszą częścią nowego systemu? Proletariat. To on w tym raju dla robotników wydawał się Le Fèvre'owi najbardziej interesujący, to w nim szukał przejawów „nowego” ${ }^{2}$. Wycieczka do jednej z fabryk włókienniczych w Moskwie obudziła w autorze wielkie nadzieje. Imponujące cyfry dotyczące produkcji, którymi go powitano (w 1913 r. wytwarzała 838 ton przędzy wełnianej, dwa lata wcześniej osiągnęła 1300 ton, w 1929 r. - 2600, a w roku przyszłym osiągnie - 3200 ton!), relatywnie wysokie zarobki (ok. 70 rubli dla robotnika niewykwalifikowanego, ok. 100 dla wykwalifikowanego), porównywalne nominalnie (ale już nie w sile nabywczej) z zarobkami robotników francuskich, pracownicza kantyna czy żłobek, wszystko to miało przekonać go, że fabryka była czymś więcej niż tylko zwykłym zakładem produkcyjnym. Ale Le Fèvre ani nie miał wrażenia, że wstąpił do „raju robotników”, ani też nawet że zobaczył prawdziwy świat robotników radzieckich. Wycieczka pozostawiła w nim silne poczucie niedosytu oraz przeświadczenie, że nie pokazano mu prawdziwej Rosji, którą mógłby oglądać i oceniać.

Nowego ducha Rosji nie znalazł też w kopalni węgla niedaleko Rostowa ${ }^{23}$. Nie zobaczył nic, czego nie znał już z kopalń północnej Francji. Lampiarnia, kantyna, łaźnie, twarde spojrzenia górników. Może jedynie tablica z wypisanymi normami produkcji wymaganymi przez centralę oraz codziennymi wynikami poszczególnych, rywalizujących ze sobą w wypełnianiu norm kopalń była nowością. Nowością był też, niepodobający się Le Fèvre’owi, wykaz górników zaznaczonych kolorem czerwonym lub czarnym. „Czerwoni”, to pracownicy dobrzy, sumienni, zaangażowani, „czarni” to ich przeciwieństwo: Iwanow nie opuścił ani jednego dnia pracy i zdecydował się oddawać ze swojej pensji 5 rubli rocznie na rzecz zwycięstwa światowej rewolucji, Smierkow przeciwnie: był leniwy, spóźniał się, nie uczestniczył w zebraniach, wytwarzał złą atmosferę. Nowego i niepokojącego go ducha czuł też Le Fèvre w gazetce wydawanej w kopalni, widział go w specjalnej rubryce w całości niemal złożonej z donosów i anonimów. O ile donos, że Efimow upił się, był tylko nie-

22 Robotnicy zostali głównymi bohaterami trzech felietonów: Le paradis du Prolétaire, J, 8 I, s. 1; Le Rouge et le noir, J, 25 I, s. 1; Le club de la mine, J, 26 I, s. 1.

23 Le Rouge et le noir, J, 25 I, s. 1. 
smaczny, o tyle informacja, że brat Rudina był popem, budziła już zaniepokojenie i negatywne odczucia wobec tegoż nowego ducha. Nowym duchem, któremu, jak stwierdził dyrektor kopalni, słowo „własność” było już „na szczęście” całkowicie obce, pachniały również warunki mieszkaniowe górników. Osiągnięciem, na razie w planach i budowie, miały być mieszkania dwupokojowe dla każdej rodziny, ale na razie Le Fèvre widział trzyosobową rodzinę śpiącą w jednym łóżku w jednopokojowym mieszkaniu, co dyrektor kopalni skwitował: wyjątkowy przypadek. Nie widział też Le Fèvre, i bardzo go to dziwiło, małych, przydomowych ogródków warzywnych. Jak sobie jednak szybko wytłumaczył, to też było zgodne z nowym duchem - ogródki czyniłyby robotników drobnymi właścicielami, właścicielami nawet tej maleńkiej przestrzeni, a to zbrodnia przecież wobec Jego Wysokości Proletariatu. Proletariat jest masą, odizolowany od tejże masy człowiek nie jest już proletariatem, jest indywiduum, a jego szczęście, jego radość i jakość życia nie są istotne.

Drugą wielką enklawą nowego porządku była wieś. Pierwsze zetknięcie z jej radziecką odmianą nastąpiło zanim jeszcze Le Fèvre opuścił Moskwę ${ }^{24}$, kiedy to zwiedzał Dom Chłopa - połączenie hotelu dla przyjeżdżających do Moskwy (np. na szkolenia i kursy czy w podróży służbowej) z czymś w rodzaju domu kultury, w którym można było znaleźć bibliotekę, czytelnię, miejsce odpoczynku i restaurację. Ten dość imponujący projekt (wedle dyrektora tejże placówki odwiedziło ją 150 tys. osób, wydano w niej 400 tys. posiłków), wzbudził w nim wielką chęć obejrzenia wsi na własne oczy i przekonania się, jaka była naprawdę, czy przypominała tę wykreowaną w Domu Chłopa, oddaną idei i lekturze ${ }^{25}$, zaangażowaną, rozwiewającą swoje dylematy lub niewiedzę przy pomocy dwóch tablic znajdujących się w świetlicy. Było to dość osobliwe urządzenie: na jednej umieszczono pytania, na drugiej odpowiedzi, obie tablice połączone były ze sobą elektrycznie i naciśnięcie guzika przy pytaniu powodowało zaświecenie się żaróweczki przy właściwej odpowiedzi. W ten oto sposób Le Fèvre uzyskał odpowiedź na swoje pytanie, w jakim punkcie znajdzie się elektryfikacja ZSRR za pięć lat: zużycie prądu wzrośnie z 5 do 20 miliardów kilowatów dzięki budowie nowych elektrowni...

Podróż na prowincję, do Bałaszowa w obwodzie saratowskim, zaprowadziła Le Fèvre’a na budzące jego żywe zainteresowanie tereny rolnicze ${ }^{26}$. Słuchał życzliwie

\footnotetext{
24 Le Mirage soviétique, J, 7 I, s. 1.

25 Choć jak zauważył, człowiek radziecki czytał w pięknej bibliotece Domu Chłopa chyba tylko wieczorami, ponieważ w ciągu dnia świeciła ona absolutnymi pustkami. Tamże.

26 Poświęcone są temu problemowi cztery felietony: Au Seul des steppes, J, 18 I, s. 1-2; Kriouchi, J, 19 I, s.1-2; L'école du déficit, J, 20 I, s. 1; L'esclave rouge, J, 21 I, s. 1.
} 
i z uwagą opowieści towarzyszących mu osób, towarzysza Glasera, mającego za sobą piękną rewolucyjną przeszłość, siedem lat więzienia carskiego, udział w rewolucji w Bucharze, pracę w wydziale propagandy w Piotrogradzie, na szczeblu regionu saratowskiego odpowiedzialnego za rolnictwo, czy też przydzielonego mu jako przewodnik i opiekun młodego komsomolca, towarzysza Pawlina. Wszyscy z zapałem wskazywali mu postępowe i nowatorskie pomysły wprowadzone przez władzę radziecką, z ideą konsolidacji ziemi i kolektywizacji na czele, przekonując z dumą, że tylko Kanada mogła poszczycić się tak wielkimi, liczącymi sobie miliony hektarów obszarami rolniczymi i że tylko kolektywizacja była w stanie sprawić, że radzieckie rolnictwo będzie wyjątkowe. Le Fèvre uprzedził swoich towarzyszy, że nie był szczególnie podatny na propagandę, używając określenia, które da się przetłumaczyć dosłownie jako „pranie mózgu”27, ale patrząc na nich, ludzi niespełna trzydziestoletnich, widział osoby, które nie uprawiały polityki, które wierzyły w to, o czym mu opowiadały, co $\mathrm{z}$ dumą mu pokazywały. Aby nie wypaczyć spojrzenia Le Fèvre’a, auto zmierzające do wzorcowego sowchozu nie zatrzymywało się w ogóle w wioskach nazywanych kułackimi. Jak to skwitował Pawlin: nic interesującego. Zgodnie też z urzędową, oficjalną retoryką machnięciem ręki zbyte zostały pytania o miejscową cerkiew, skoro bywał tam z tuzin staruszków jedynie, a pop pracował w kuźni.

Ale oto i cel podróż ${ }^{28}$. Dyrektor sowchozu, młody i zaangażowany, poprowadził ich do świetlicy pełnej plakatów i czerwonych flag, z portretem Stalina w centralnej części. Salę z dumą zaprezentowano gościowi, pilnie obserwując jego reakcje, szczególnie, kiedy stanął przed żarówką symbolizującą postęp. Choć to raczej zapowiedź postępu dopiero, ponieważ jest żarówka, ale nie ma ani kabla, ani prądu, ani niczego, co tenże prąd przywiedzie do sowchozu, ani też nikogo, kto go wytworzy... Le Fèvre nie dyskutował z tym, jak się wyraził, młodzieńczym entuzjazmem, nie chcąc urazić godności młodzieży, ale obraz postępu był dość jednoznaczny. W drugim obrazku widać młodych ludzi zgromadzonych w niedzielne popołudnie w sowchozowej świetlicy, którzy bez zapału i entuzjazmu, zajęci bardziej swoimi sprawami słuchają przemówienia na temat misji, jaką ich sowchoz wypełniał w regionie, stając się wzorcem dla pozostałych osad, będąc awangardą przyszłości. Najbardziej jednak Le Fèvre’a zafascynowała strona ekonomiczna całego przedsięwzięcia. Liczyło ono sobie 3 tys. hektarów ciągnącego się po horyzont czarnoziemu, uprawiano ziemniaki, słonecznik, pszenicę i żyto, dysponując 20 potężnymi traktorami, miejscowa

\footnotetext{
27 „Bourrer le crâne”.

28 L'école déficit, J, 20 I, s. 1.
} 
cegielnia produkowała 1,2 mln cegieł rocznie, zatrudniano dobrze wykształconych fachowców. Le Fèvre dociekliwie wypytał o produkcję, koszty oraz zyski i doszedł do niespodziewanej i jakby niemiłej dla dyrektora sowchozu konkluzji. Zestawienie rocznej produkcja zboża (90 tys. pudów ${ }^{29}$, z czego państwu sprzedawano ok. 75 tys.), jego ceny (ok. 1 rubel za pud) z kosztami utrzymania traktorów i traktorzystów (ok. 17 tys. rubli), pensji pozostałych członków wspólnoty (ok. 45 tys.), 15 tys. rubli amortyzacji, 10,5 tys. innych kosztów - to 12,5 tys. rubli deficytu, w jaki sposób funkcjonowało więc to gospodarstwo? Pożyczki państwowe. Jeszcze pożyczki?!?!?! Ale to odsetki! To sprawiało, że koszty wynosiły dużo więcej i ponosił je każdy obywatel! „To nas nie dotyczy” odpowiedział niezadowolony dyrektor sowchozu, oskarżając Le Fèvre’a o szpiegostwo ekonomiczne, aż musiał interweniować Pawlin, przywołując gościa do porządku i kończąc tę pouczającą lekcję ekonomii. Jeszcze większe zdumienie Le Fèvre’a, połączone z przeświadczeniem o kłopotach ze słuchem, wzbudził jeden z lokalnych urzędników Ludowego Komisariatu Rolnictwa w czasie wizyty w sowchozie „Czerwony Październik”" Tłumaczył bowiem z zapałem, że największym błędem początku rewolucji było rozdanie ziemi chłopom. Jeżeli bowiem dysponuje się dziesiątkami milionów hektarów ziemi oraz dziesiątkami milionów rąk do pracy, jak ma to miejsce w ZSRR, trzeba stworzyć odgórną doktrynę zarządzania nimi, wymaga tego bezwzględnie interes gospodarczy państwa. I w żadnym razie nie był to powrót do wielkiej własności, jak sugerował Le Fèvre! Wielka własność prywatna i wielka własność państwowa, to dwa zupełnie różne światy. Kiedyś chłopi byli „niewolnikami pracującymi na swoich głupich panów utrzymujących tancerki w teatrze", a dzisiaj chłop pracuje dla wszystkich, dla powodzenia całego narodu. A to oznacza również pracę dla własnego szczęścia! I miejsca takie, jak „Czerwony Październik” służą praktycznemu oświeceniu mas, pomagają zrozumieć, gdzie tak naprawdę leży ich interes. Sam sowchoz to 35 tys. hektarów, uporządkowane z wojskową precyzją zabudowania, garaże, magazyny i biura wznoszące się nad płaskim stepem i sprawiające surowe wrażenie koszar ${ }^{31}$. Wspaniałe maszyny, wielkie amerykańskie traktory, imponujący rozmach i byli wieśniacy pracujący jako robotnicy rolni. Dzięki stworzeniu sowchozu udało się odciągnąć ich od kułaków, zapewnić pensję i stałą pracę, nie potrzebowali więc własnej ziemi, zresztą kiedy mieliby na niej pracować? retorycznie pytał Le Fèvre’a dyrektor „Czerwonego

\footnotetext{
291 pud to ok. $16 \mathrm{~kg}$.

30 L'esclave rouge, J, 21 I, s. 1.

31 Tamże.
} 
Października”. A warunki pracy? No cóż... 1 rubel 30 kopiejek dziennie. Niedużo, ale była tania kantyna, darmowy nocleg pod gwiazdami ${ }^{32}$, w przyszłości nowe mieszkania dla rodzin. W kantynie Le Fèvre dokonał szybkich rachunków: talerz kapuśniaku z wkładką mięsną oraz miska klusek kosztowały 36 kopiejek, ponieważ to ludzie $\mathrm{z}$ dobrym apetytem, jadali trzy razy dziennie, zostawały więc 22 kopiejki. Jak za to żyć? Utrzymać żonę i dzieci? Kupić papierosy?

Dla Le Fèvre’a konkluzja była jasna: rzeczywiście rozdanie ziemi chłopom było błędem. Stworzenie stu milionów drobnych właścicieli nie było potrzebne nowemu systemowi. Wręcz przeciwnie: system potrzebował stu milionów biednych mężczyzn, potrzebował stworzenia proletariatu wiejskiego obok proletariatu robotników, biedaków, którzy będą pracować za minimalną płacę przywiązani do ziemi kontraktami. System potrzebowal nowych niewolników. Co za zdumiewający wniosek ponad 130 lat po wyzwoleniu czarnych niewolników we francuskich koloniach. Spotkany w pociągu do Moskwy przypadkowy podróżny opowiedział też Le Fèvre'owi o miejscu zdecydowanie nieznajdującym się na szlaku podróży zagranicznego gościa: Wyspach Sołowieckich, na których spędził półtora roku ${ }^{33}$. Francuski dziennikarz usłyszał relację, która zdecydowanie rozszerzała znaną mu definicję archipelagu jako miejsca zsyłki kleru i osób podejrzanych ${ }^{34}$. Relację o pobycie w areszcie bez możliwości kontaktu z rodziną, bez listów, które nie docierały, z jednym kontaktem przez Czerwony Krzyż, któremu udało się dostarczyć zesłańcowi nieco ubrań. O podróży w wagonie bez okien i toalety, z jedną porcją chleba i śledziem jako posiłkiem oraz dwoma racjami gorącej wody. O diecie złożonej z gotowanych ryb, ziemniaków, bochenka chleba i porcji grochu dziennie. O 20-30-stopniowych mrozach, nocy polarnej, nieprzystosowaniu do życia w takich warunkach większości zesłańców. O wspólnych grobach, jeżeli ktoś nie miał kilkunastu rubli, aby opłacić mu dyskretnie grób indywidualny. O niezwykle ciężkiej pracy w skrajnych warunkach przy wyrębie drzew. Jednak starania o możliwość osobistej weryfikacji tej opowieści nie udały się: akurat w tym roku, jak usłyszał Le Fèvre, statek kursujący na Wyspy Sołowieckie przestał pływać 1 listopada, a nie 1 grudnia jak zwykle, z powodu wcześniejszej zimy oczywiście.

Wplecione w różne felietony pojawiały się też sprawy dotyczące codzienności: mieszkania, podróży, wizerunku Rosji w przewodnikach, rosyjskiej duszy, ale też pozo-

\footnotetext{
32 Le Fèvre używa słowa kemping.

33 Solovki. Terre d'exil, J, 27 I, s. 1-2.

34 Por. D. Tołczyk, Gułag w oczach, s. 112-121.
} 
stających na marginesie ludzi związanych ze starym światem. Nie tylko bowiem entuzjastów nowego systemu udało się Le Fèvre’owi spotkać. Nie tylko tych, którym błyszczały oczy i opowieściami o komunizmie upijali się jak najprzedniejszym koniakiem ${ }^{35}$. Pod znamiennym tytułem „Vieilles souches” ${ }^{36}$ opowiedział o spotkaniu z grupą osób nie do końca z nowym systemem ułożonych, choć żyjących w nowej Rosji. Przedrewolucyjny książę, poeta, samotna kobieta, Mme R., wywodząca się z zamożnej warstwy mieszczańskiej udzielająca lekcji języka angielskiego. Ich życie toczyło się z dnia na dzień, finanse uniemożliwiały wyjazd, pochodzenie - otrzymanie zgody, a nawet gdyby był realny, odbierałby możliwość powrotu, coś, z czym nie byli w stanie się zmierzyć. Poeta utrzymywał się, pisząc wiersze o radzieckim zbożu i hymny na cześć radzieckich rolników, dająca lekcje Mme R. nigdy nie wiedziała, kiedy skończą się jej kolejne zlecenia, książę, który pięć lat przesiedział w więzieniu, ale pogodził się z reżimem, został właśnie zwolniony z banku, gdzie pracował i mieszka kątem u przyjaciela, śpiąc w kuchni. Pozbawieni prawa głosu (książę i Mme R. z przyczyn oczywistych, poeta, ponieważ miał wuja popa) mieli dwa razy wyższe koszty życia - pozbawienie praw wyborczych pozbawiło ich również kartek żywnościowych i uważali to za znacznie gorszą przypadłość niż brak prawa głosu. Bo jakież było to głosowanie? Wybór między komunistą blondynem a komunistą brunetem, między komunistą wysokim a komunistą niskim... Ale niezależnie od wszystkiego - tu jest dom. Nawet jeżeli tenże dom, to wielorodzinne mieszkania, restauracje zamienione w stołówki, kłopoty z pracą i nieustanne borykanie się z problemami finansowymi.

A jak żyło się ludziom we Francji? To pytanie pojawiało się dosyć często, prowokując Le Fèvre’a do polemik z przyjętym przez jego rozmówców z góry założeniem, że radziecki proletariat żył lepiej, świadomiej, pełniej, bardziej ${ }^{37}$. I słowa Le Fèvre’a nie brzmiały dla nich przekonująco, nawet kiedy tłumaczył, że w wielu miejscowościach górnicy na północy Francji mieli czteropokojowe domki, z małym ogródkiem i piwnicą, w dodatku niekiedy mieli szansę po dwudziestu latach zostać - o zgrozo! - ich właścicielami ${ }^{38}$, zamiast żyć w jednej izbie z mglistą obiet-

35 Confidences de Vania jeune Russe, J, 16 I, s. 1.

36 Co dosłownie oznacza stare, zbędne gałęzie, kikuty, zwiędłe już i martwe części drzew i krzewów, a w przenośni w tym wypadku oznacza złogi, pozostałości starego porządku.

37 Le Rouge et le noir, J 25 I, s. 1.

38 Słowo „właściciel”, „posiadacz” sprowokowało rozmówcę Le Fèvre’a do dość ostrej wypowiedzi, w której poinformował go, że pojęcia te zniknęly na szczęście ze słownika radzieckiego człowieka. Generalnie z rozmów Le Fèvre’a jasno wynika, że był to rodzaj „brzydkiego wyrazu”, coś, o czym nie mówiło się i czego unikało się w kulturalnej rozmowie. 
nicą dwuizbowego, jeszcze nie wybudowanego, mieszkania w przyszłości. Kwestia mieszkaniowa oraz sprawa posiadania (czegokolwiek) były najbardziej delikatnymi w rozmowach o Francji. Opiekun i tłumacz Le Fèvre’a Wania, towarzyszący mu przez cały pobyt, z lekceważeniem wypytywał go o stan posiadania w Paryżu, mieszkanie, samochód i zgryźliwie obiecywat, że ten dobrobyt będzie trwał tylko do czasu, aż zawita tam radziecka rewolucja ${ }^{39}$. A informację o tym, że dziennikarz mieszka sam w całym mieszkaniu, skwitował okrzykiem: co za wstyd! O Francję wypytywały też Le Fèvre’a młode dziewczęta, które spotkał w konserwatorium w Niżnym Nowogrodzie, z zapałem wyciągając z niego informacje o modzie i fryzurach, dowodząc, że nawet w radzieckiej Rosji Francja pozostawała pewnym stylowym punktem odniesienia ${ }^{40}$. Młode małżeństwo poznane na spacerowym statku w Leningradzie po przełamaniu pierwszej nieufności z ciekawością wypytywało o francuską codzienność i zaprosiło go do siebie, żeby zobaczyl, jak żyli zwykli Rosjanie ${ }^{41}$. Wielorodzinne mieszkanie w centrum Leningradu. Mały pokoik. Mniej niż ustawowe $11 \mathrm{~m}^{2}$ na osobę ${ }^{42}$. Wspólna kuchnia. Prymus. Biurko będące jednocześnie stołem. Obrus z „Izwiestii”. Przycisk do papieru w kształcie popiersia Lenina. Talerz z rybą i kiszonymi ogórkami. Trójka współlokatorów jedząca późne, niedzielne śniadanie. Wielka wiara w system i plan pięcioletni. I odwrotnie: przypadkowo spotkany podczas spaceru pracownik sklepu z odzieżą, który z goryczą mówił: zarabiam jak kiedyś 120 rubli, ale mam teraz żonę i trójkę dzieci, a życie jest dwa razy droższe, mieszkanie ma $10 \mathrm{~m}^{2}$, kartki na chleb, kartki na mięso, kartki na cukier i te w dodatku w połowie wymiaru, bo nie jestem robotnikiem. Oto życie. Pasjonujące życie w kraju elektryfikacji i planu pięcioletniego. To jednak rzadkie spotkanie, zdecydowana większość rozmówców Le Fèvre’a to mniej lub bardziej szczerzy entuzjaści nowej Rosji. Ale też Le Fèvre doskonale zdawał sobie sprawę z tego, że większość tego, co widział, tego, z kim i o czym rozmawiał, to, gdzie mógł pojechać, było tym, co gospodarze chcieli mu pokazać i przekazać. I że chcąc dowiedzieć się czegoś prawdziwego, musiał pilnie, pilniej niż gdzie indziej patrzeć, słuchać i zaglądać pod powierzchnię rzeczy $^{43}$. Nie było to łatwe, kiedy od samego początku towarzyszył mu przewodnik/ tłumacz, na każdą wizytę musiał uzyskać pozwolenia i specjalne zgody, a poruszać

\footnotetext{
39 Confidences de Vania jeune Russe, J, 16 I, s. 1.

40 Jeunesse d'état, J, 14 I, s. 2.

41 Dimanche soviétique, J, 9 I, s. 1; Ames soviétiques, J, 10 I, s. 1.

42 Ten luksus oferowany jest tylko w nowo wybudowanych mieszkaniach.

43

Appareillage, J, 11 I, s. 1.
} 
się zaakceptowaną trasą zgodnie z zasadami ustalonymi dla zagranicznych gości ${ }^{44}$. Ale z drugiej strony z zaskakującą łatwością, mimo bariery językowej i obecności tłumacza najczęściej, niekiedy tylko spotykając kogoś znającego j. francuski, rozmawiał z ludźmi, zaskakująco często ludzie ci opowiadali mu o rzeczach, które nie mieściły się w oficjalnym katalogu relacji o nowym państwie. Także różnorodność ludzkich typów, z którymi stykał się, szczególnie podczas podróży, na statku, w pociągach, ale też na spacerach, pozwoliła Le Fèvre'owi znacząco poszerzyć percepcję, nawet jeżeli niekiedy rozmowa czy spotkanie zaczynało się od nieufności oraz zdumienia, które budzil, szczególnie na prowincji, swoim beretem i skórzaną kurtką ${ }^{45}$. Podróże okazały się nieocenionym źródłem informacji, niwelując częściowo ograniczenia związane z przemieszczaniem się po ZSRR cudzoziemskiego dziennikarza i kontrolą kontaktów podlegających starannej selekcji. Dworce, wagony różnej klasy, długie, nocne peregrynacje pomiędzy Moskwą a Rostowem czy Petersburgiem ${ }^{46}$ pozwalały rozszerzyć zakres koncesjonowanych obserwacji, choć jak się wydaje, nie zmieniły one zasadniczo perspektywy Le Fèvre'a.

Od samego początku krytyczny, czujny, tropiący fałsz i propagandowe nuty w przekazywanym mu obrazie ZSRR, szukający rysów nowego świata, ale jednocześnie zdecydowanie nieprzekonany o jego wyższości Le Fèvre starał się pokazać to, co wydawało mu się istotą nowej Rosji. Rozsiał te obserwacje we wszystkich felietonach, wykorzystując różne preteksty do ich sformułowania. Wszechobecna propaganda, sztuka, ośrodki opiekuńcze dla dzieci, zakłady pracy wykorzystujące jednakową matrycę do modelowania nowego człowieka. Gorliwa wiara jednych i pragmatyczny sposób na przetrwanie innych. Oznaki ekonomicznej hochsztaplerki, próby wyparcia w ludziach potrzeb materialnych, starania o nadanie sensu ich życiu uczestnictwem w czymś wyjątkowym, budząca niesmak próba sprowadzenia kultury do funkcji wybitnie utylitarnych i propagandowych. Szczególny nacisk, jaki państwo położyło na formatowanie nie tylko zachowań, ale i myśli. Duch i obyczaj, oto płaszczyzny, na których najgorliwiej, z pasją i uparcie wprowadzano to, co miało być nową Rosją ${ }^{47}$.

\footnotetext{
44 D. Tołczyk, Gutag w oczach, s. 131-134.

45 Dimanche soviétique, J, 9 I, s. 1; Ames soviétiques, J, 10 I, s. 1.

46 Un Wagon, J, 12 I, s. 1; Le Soubotnick, J, 17 I, s. 1; Wagon mou, J, 24 I, s.1; De la Baltique à la mer Noire, J, 3 II, s. 1-2; De la Baltique à la mer Noire, J, 3 II, s. 1-2.

47 O. Figes, Taniec Nataszy, s. 335-338; R. Grzybowski, Idea wychowania „nowego człowie$k a$ " (homo sovieticus) i jej odzwierciedlenie w zatożeniach programowych wszechzwiązkowej organizacji pionierskiej, Polska Myśl Pedagogiczna 4 (2018), s. 297-322. Mechanizm tworzenia
} 
Obserwacje Le Fèvre’a były mocno krytyczne. Niewyrażone może zbyt bezpośrednio wobec gospodarzy, wybrzmiały jednoznacznie w napisanych już tekstach. Bardzo ironiczne, podkreślające zgrzebność i biedę tego „raju robotników”, nieomieszkujące wszędzie, gdzie było to możliwe, wskazać paradoksy, niekonsekwencje, czy wręcz rozbieżność teorii i praktyki systemu. Ludzie przekonywani, że potrzebowali jedynie pracy dla dobra wspólnego w miejsce własnych aspiracji i potrzeb, szczególnie materialnych, redukowani do bezkształtnej wspólnoty, obdzierani ze wszystkiego, co indywidualne. Służący systemowi. Wychowywani do i dla tego systemu. Ale co ciekawe - postrzegani przez Le Fèvre'a w podobnych kategoriach, jak wytwory wychowania zachodniego kapitalizmu: trybiki w systemie pracujące za minimalne wynagrodzenie i odpowiednią podbudowę ideologiczną ${ }^{48}$.

Obraz, który trafil do rąk francuskiego czytelnika, nie był idyllicznym obrazem raju. Nastawiony sceptycznie Le Fèvre przekonał się na miejscu, że spotkani przez niego ludzie żyli, pracowali, jedli, spali, kochali i zajmowali się swoimi sprawami, wbrew temu, czego mógł się spodziewać ktoś podświadomie utożsamiający nową władzę w Rosji ze śmiercią, głodem, biedą i strachem ${ }^{49}$. Ale też wyraźnie widział proces „lepienia” nowego człowieka i produkt końcowy tego procesu, zideologizowany albo cyniczny wyznawca systemu, zdecydowanie nie przypadł mu do gustu. Pocieszał się, że wyznawcy brali się z krótkiego stażu nowego państwa ${ }^{50}$, ale widząc zaangażowanie władz, nie wątpił, że dostrzeżenie przez większość nielogiczności i niesprawiedliwości nie nastąpi zbyt szybko. Zachwycony Rosją rozumianą jako apolityczny twór, jej rozmiarem, bogactwem przyrody, różnorodnością, otwartymi i serdecznymi ludźmi nie miał wątpliwości, że idea stworzenia raju na ziemi okazała się kolejnym złudzeniem. Wydaje się, że Le Fèvre nie spełnił nadziei pokładanych w zagranicznych gościach, którzy mieli swoimi tekstami budować na Zachodzie pozytywny wizerunek ZSRR. Jego poglądy i społeczna wrażliwość pozwalały domniemywać, że okaże się użytecznym narzędziem propagandy, co z pewnością miało wpływ na wydanie wizy wjazdowej. Jednak generalną konkluzję jego obserwacji można zamknąć w stwierdzeniu, że „nowy świat” to świat osadzony w propagandzie, przenikającej każdą dziedzinę życia, to codzienność przygniatająca wręcz obecnością ideologii i państwa, pozbawiająca człowieka jego indywidualnego znaczenia

nowego człowieka wspaniale przedstawiono w pracy: M. Heller, Maszyny $i$ śrubki: jak hartowat się człowiek sowiecki, Paryż 1988.

48 Jeunesse d'état, J, 14 I, s. 1.

49 Le club de la mine, J, 26 I, s. 1.

50

Le Soubotnick, J, 17 I, s. 1. 
na rzecz wspólnoty, to wyrzeczenie się osobistych pragnień i potrzeb, budowanie owego „nowego” nie przez tworzenie nowej rzeczywistości, ale za sprawą kreowania nowej mentalności. Nie był to obraz jedyny, w okresie międzywojennym w językach francuskim, polskim, angielskim powstało wiele relacji opisujących z różnych punktów widzenia radziecką rzeczywistość, jednak te krytyczne nie były normą. I to wydaje się jedną z największych zalet tekstów Le Fèvre’a. Czytelnicy „Le Journal” otrzymali barwny, dzięki soczystemu językowi atrakcyjny w lekturze, zdumiewająco realny obraz ZSRR, stanowiący głośno przemawiający kontrapunkt wobec jego tworzonego oficjalnie wizerunku. Obraz fascynujący, zatrzymany w kadrze, uchwycony w swojej codzienności i dzięki temu wyjątkowy, autentyczny i cenny.

\author{
Dr hab. Małgorzata Nossowska \\ Uniwersytet Marii Curie-Skłodowskiej w Lublinie \\ Instytut Historii \\ pl. Marii Curie-Skłodowskiej 4a \\ 20-031 Lublin \\ e-mail: mnoss@tlen.pl \\ Nadesłany 31 X 2019 \\ Przesłany po poprawkach recenzyjnych 9 IV 2020 \\ Zatwierdzony 20 VII 2020
}

\title{
Summary
}

In early 1930, "Le Journal", one of the most popular and widely read Parisian newspapers, published a series of texts devoted to Soviet Russia. They were fragments of a book entitled "Un Bourgeois au pays des sovièts" written by journalist Georges Le Fèvre, published in 1929 as a result of a several-week-long trip around the Soviet Union. During his travel, Le Fèvre kept under thoughtful yet critical observation the results of the 12 years during which the new political system had operated. He also gave some thought to the daily life and leisure time, providing the French readers with a picture of the new Russia that was colourful but not free of criticism. Notably, the fragments of the book were published in "Le Journal", a newspaper with a strong right-wing bias. Thus Le Fèvre had an opportunity to get his message across to several million readers, an audience larger than in the case of his book, and to present to them his image of the USSR in a key moment of the upcoming change in the political relations between France and Russia. 